\title{
The inhibitory effect of Eupatorium adenophorum extracts on the pathogen of postharvest disease of banana
}

\author{
Zhao Weifeng ${ }^{1,2}$, Yang Weixiu ${ }^{1}$, Li Ying $^{3}$, Cao Junying ${ }^{4}$, Yang Xiaohuan ${ }^{3}$, and Ma Jinhu ${ }^{4 *}$ \\ ${ }^{1}$ College of Tropical Crops, Yunnan Agricultural University, 665000 Pu'er, Yunnan, China \\ ${ }^{2}$ South Subtropical Crop Research Institute, Chinese Academy of Tropical Agricultural Sciences, 524091 Zhanjiang, Guangdong, China \\ ${ }^{3}$ College of Agriculture, Shanxi Agricultural University, Taigu, Shanxi 030801, China \\ ${ }^{4}$ College of Engineering, Shanxi Agricultural University, Taigu, Shanxi 030801, China
}

\begin{abstract}
The Colletotrichum musae and Fusarium semitectum Berk., Which often occur in banana after harvest were used as the targets. Three components with antibacterial activity extracted from the leaves of the plant were used as "fungicide". The antibacterial effect of the three component substances on the pathogens of anthracnose and shaft rot was studied. The results showed that the inhibitory rates of the components $\mathrm{A}, \mathrm{B}$ and $\mathrm{C}$ at $2 \mathrm{mg} / \mathrm{ml}$ on the pathogens of banana anthracnose and shaft rot reached $82.53 \%$, $79.91 \%, 78.30 \%$ and $82.2 \%, 78.69 \%$ and $81.17 \%$ respectively. The EC 90 values of component $\mathrm{A}, \mathrm{B}$ and $\mathrm{C}$ for banana anthracnose pathogens were $1.70,1.85$, and $1.69 \mathrm{mg} / \mathrm{ml}$. Respectively, the EC90 values for banana shaft rot pathogens were $1.37,1.38$, and $1.64 \mathrm{mg} / \mathrm{ml}$. The antibacterial effect of the three component substances on the pathogen of banana shaft rot was better than that of anthracnose. The three component substances have great potential for controlling post-harvest anthracnose and shaft rot of bananas.
\end{abstract}

\section{Introduction}

Bananas are the main tropical fruits in China, with huge consumption. Bananas are susceptible to a variety of diseases during the post-harvest storage and transportation process, resulting in serious fruit rot, affecting the quality of bananas, and causing major economic losses. According to incomplete statistics, there are more than 60 kinds of fungi, 6 kinds of bacteria and 3 kinds of physiological causes that cause postharvest diseases of bananas. Among them, the most common and serious diseases are anthracnose and shaft rot ${ }^{[1]}$. At present, banana postharvest diseases and freshkeeping mainly rely on chemical fungicides. For example, the use of carbendazim, tedocor, prochlorin, prochloraz and other chemical agents to soak fruits could prevent and control post-harvest diseases of bananas ${ }^{[2-3]}$, but the use of chemical sterilization is easy to make the bacteria resistant, and the environment and fruits Cause pollution and endanger public health. The use of green pollution-free biological prevention and control technology to prevent and control the post-harvest diseases of bananas has increasingly attracted the attention of producers and scientific researchers ${ }^{[4]}$. Hu et al. ${ }^{[5]}$ found that the clove, baicalin and gallnut acetone extracts had a good inhibitory effect on the anthracnose of mango and banana. Wu et al. ${ }^{[6]}$ reported that treatment of postharvest banana fruits with methanol extract, ethyl acetate and n-butanol extract of open arrow can significantly reduce the incidence of latent anthrax. He et al. ${ }^{[7]}$ reported that the use of petroleum ether, acetone, ethyl acetate, and ethanol extracts of Shichangpu had a certain inhibitory effect on the pathogenic bacteria of Mango anthracnose.

Eupatorium adenophorum (Eupatorium adenophorum) is a perennial, clustered evergreen semishrub plant, is a worldwide malignant weed. Eupatorium adenophorum plant is rich in natural active substances, and its extract has a strong allelopathy effect on various plants, pathogenic microorganisms and pests, significantly inhibits the growth and development of plants, and has a certain control effect on plant fungal diseases and insect pests ${ }^{[8,9]}$ It is expected to be developed as a plant fungicide for green control of plant fungal diseases and post-harvest fruit diseases.

In this experiment, the extracts of Eupatorium adenophorum and ethyl acetate were used to target the pathogenic bacteria of two kinds of fungal diseases, such as anthracnose and axis rot, which are prone to banana harvest. The antibacterial activity of the components on the pathogenic bacteria of banana anthracnose and axis rot was studied. The purpose is to provide a theoretical basis for the application of Eupatorium adenophorum extract in the prevention and control of banana postharvest diseases.

\footnotetext{
* Corresponding author: mjh109@126.com
} 


\section{Materials and methods}

\subsection{Materials}

Colletotrichum musae (Berk. et Curt.) Arx) and axis rot fungus (Fusarium semitectum Berk. et Rav.) are isolated from the diseased fruits of mature bananas. Select strains with strong pathogenicity to save for future use. The above strains were transferred to PDA medium plate $\left(28^{\circ} \mathrm{C}\right)$ and cultured for 2 to 5 days, and they were used for testing after meeting the inoculation requirements. Mature leaves of Eupatorium adenophorum (collected from Pu'er City, Yunnan Province); Carbendazim (50\% wettable powder, produced by Jiangsu Yanfeng Biological Chemical Co., Ltd.); promethamine water emulsion (active ingredient 450g / L) (Manufactured by Shanghai Yuelian Chemical Co., Ltd.).

\subsection{Measurement items}

The preparation method of the components of different Eupatorium adenophorum extracts. After the leaves of Eupatorium adenophorum are shade dried, crushed to a size of $2-5 \mathrm{~mm}$, add $95 \%$ ethanol according to the material-liquid ratio of $1: 8-1: 12$, extract under reflux at $80-85{ }^{\circ} \mathrm{C}$ for $2 \mathrm{~h}$, extract twice, and combine extracts Concentrate to obtain crude extract. The crude extract was loaded into a chromatography column, eluted with petroleum ether $\left(60-90{ }^{\circ} \mathrm{C}\right)$ and ethyl acetate solvent in sequence, and the eluent was concentrated to obtain petroleum ether extract and ethyl acetate extract, respectively. Load the petroleum ether extract into the chromatographic column, elute with two different polar eluents (petroleum ether and ethyl acetate mixed solution) in sequence, and concentrate the eluent to obtain two purple stems, $\mathrm{A}$ and $\mathrm{B}$, respectively Zelan extract component substance; the ethyl acetate extract was packed into a column, and eluted with a mixed eluent of petroleum ether and ethyl acetate, and the eluent was concentrated to obtain the E. adenophorum extract C component substance. Put the three component materials $\mathrm{A}, \mathrm{B}$ and $\mathrm{C}$ in a low-temperature vacuum drying oven to evaporate the eluent to a balanced weight, and store at $4{ }^{\circ} \mathrm{C}$ in a dark place away from light.

Antibacterial activity of different Eupatorium adenophorum extracts against two pathogens. Using the growth rate method ${ }^{[10]}$, according to the preliminary experiment on the sterilization activity of Eupatorium adenophorum extract, the three Eupatorium adenophorum extract components were dissolved with a small amount of ethyl acetate $(1 \mathrm{~g} / 10 \mathrm{~mL})$, and the concentration was 100 The mother liquor of $\mathrm{mg} / \mathrm{mL}$ is reconstituted into drug-containing PDA plates with concentration gradients of $0.1,0.5,1.0,1.5$ and $2.0 \mathrm{mg} /$ $\mathrm{mL}$, and the two pathogens are prepared with a punch $(\Phi$ $=0.50 \mathrm{~cm})$ The bacterial plate is then inoculated on the drug-containing plate. Taking $2.0 \mathrm{mg} / \mathrm{mL}$ ethyl acetate PDA plate as a control (CK), it was incubated at $28^{\circ} \mathrm{C}$ under constant temperature. After 5 days of cultivation, the diameter of the colony was measured to calculate the growth inhibition rate of the colony at different concentrations. Find the probability value of bacteriostatic rate (y), and calculate the logarithmic value $(x)$ of each concentration. Use the logarithmic value of concentration $(\mathrm{x})$ and the probability value of bacteriostatic rate $(\mathrm{y})$ to find the virulence regression equation $\mathrm{y}=\mathrm{ax}+\mathrm{b}$, and calculate the half-maximal effect concentration $\left(\mathrm{EC}_{50}\right)$ and correlation coefficient $(\mathrm{r})$ for inhibiting colony growth ${ }^{[11]}$. The colony growth inhibition rate was repeated 3 times for every 3 dishes. Colony growth inhibition rate $/ \%=$ (control colony diameter-treated colony diameter) / control colony diameter $\times 100$.

Comparison of antibacterial activities of different Eupatorium adenophorum extract components against two pathogens. In the same way as above, the three Eupatorium adenophorum extracts were divided into 0.1, $0.5,1.0,1.5$ and $2.0 \mathrm{mg} / \mathrm{mL}$ concentration gradient drug-containing PDA plates, and the two pathogens were inoculated on the drug-containing plates, The culture was carried out at a constant temperature at $28^{\circ} \mathrm{C}$. After 5 days of cultivation, the diameter of the colony was measured to calculate the growth inhibition rate of the colony at different concentrations. Set $1 \mathrm{mg} / \mathrm{mL}$ concentration of carbendazim (code D) and prochloraz (code $\mathrm{M}$ ) (concentration recommended for production) as a reference, compare 3 different components with carbendazim and prochloraz Antibacterial effect of pathogenic bacteria.

\subsection{Statistical analysis}

The statistics of experimental data was conducted using Excel 2007 and was analyzed using Duncan's new complex range method by software DPS v9.50.

\section{Results and analysis}

\subsection{Antibacterial activity of three component substances against two pathogenic bacteria}

It can be seen from Figures 1 and 2 that as the concentration of the components of the extracts of Eupatorium adenophorum increases, the antibacterial activity of the extract components against the two pathogens gradually increases, and the antibacterial rate increases. When the concentration of component $\mathrm{A}, \mathrm{B}$ and $C$ is $0.1 \mathrm{mg} / \mathrm{mL}$, the bacteriostatic rates of banana anthracnose pathogen (Figure 2A) and axis rot pathogen (Figure 2B) are 5.93\%, 7.29\%, 5.67\% and 18.00, respectively $\%, 41.58 \%, 20.10 \%$. At $2 \mathrm{mg} / \mathrm{ml}$, the bacteriostatic rate of banana anthracnose and axis rot pathogens reached $82.53 \%, 79.91 \%, 78.30 \%$ and $82.2 \%$, $78.69 \%, 81.17 \%$; relatively speaking, components A, B and $\mathrm{C}$ The antibacterial effect of the substance on the pathogen of banana axis rot is better than that of banana anthracnose. At relatively low concentrations $(0.5 \mathrm{mg} /$ $\mathrm{mL}$ ), the bacteriostatic rates of $\mathrm{A}, \mathrm{B}$, and $\mathrm{C}$ components on the pathogen of banana axis rot are $64.92 \%, 64.63 \%$, and $59.48 \%$ (the bacteriostatic rates are all greater than $50 \%$ ), and The bacteriostasis rate of banana anthracnose pathogens was $41.32 \%, 49.3 \%$ and $47.47 \%$ (less than 
$50 \%$ ); the bacteriostatic effect of A pathogen, component $\mathrm{A}, \mathrm{B}$ and $\mathrm{C}$ components was investigated separately,
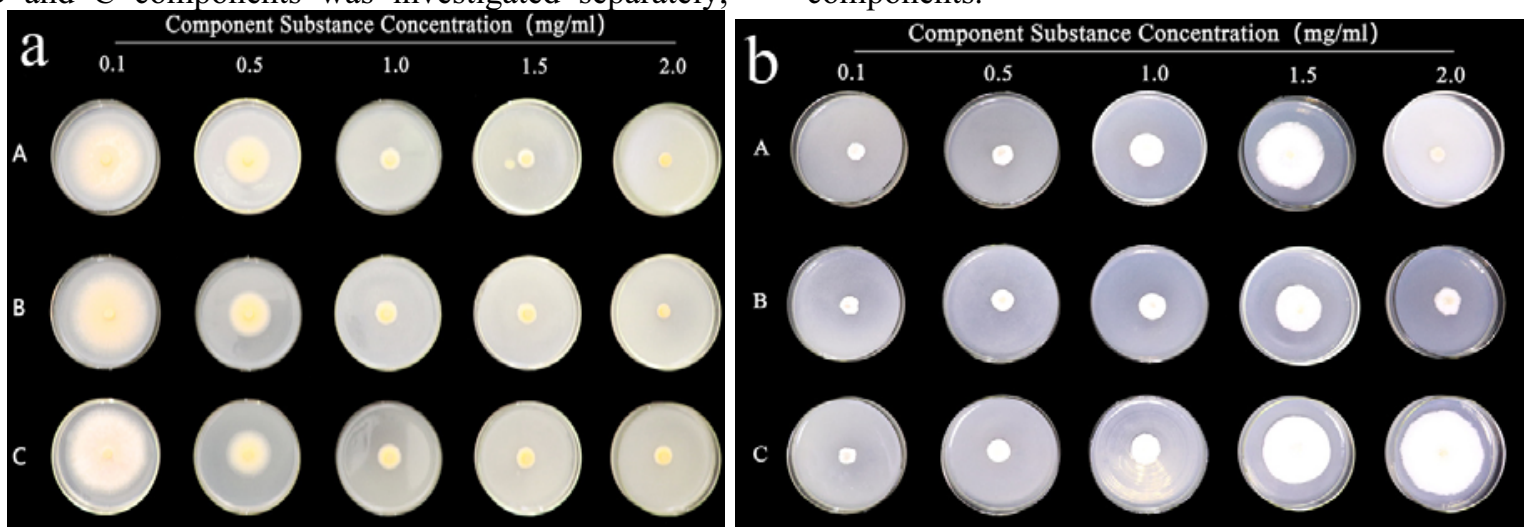

Fig.1 Bacteriostatic effects of three constituent substances on the pathogens of banana anthracnose(a) and shaft rot(b) pathogens
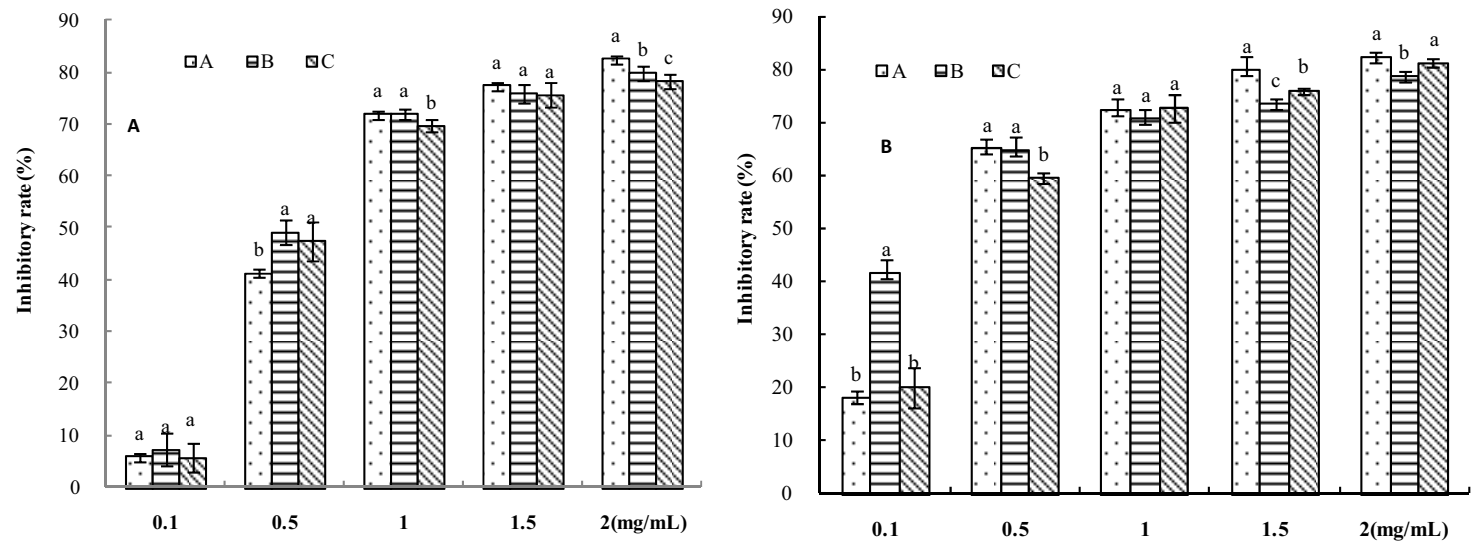

Fig.2 Bacteriostatic rate of the three constituent substances on the pathogens of banana anthracnose(A) and shaft rot(B) pathogens

\subsection{Toxicity of 3 extracts to 2 pathogens}

It can be seen from Table 1 that the $\mathrm{EC}_{50}$ values of $\mathrm{A}, \mathrm{B}$ and $\mathrm{C}$ components for banana anthracnose pathogens are $0.48,0.45$ and $0.66 \mathrm{mg} / \mathrm{mL}$, and the $\mathrm{EC}_{90}$ values are $1.70,1.85$ and $1.69 \mathrm{mg} / \mathrm{mL}$, respectively; A, B and C The $\mathrm{EC}_{50}$ values of the component substances on the pathogen of banana axis rot were $0.27,0.33$ and $0.27 \mathrm{mg}$ / $\mathrm{mL}$, and the $\mathrm{EC}_{90}$ values were 1.37, 1.38 and $1.64 \mathrm{mg} /$ component A was slightly better than B And C components.

Table 1. The virulence effect of three components on two pathogens

\begin{tabular}{|c|c|c|c|c|c|}
\hline Extract component & Pathogen & $\mathrm{Y}=\mathrm{aX}+\mathrm{b}$ & $\mathbf{R}$ & $\begin{array}{c}\mathrm{EC}_{50} \\
(\mathrm{mg} / \mathrm{mL})\end{array}$ & $\begin{array}{c}\mathrm{EC}_{90} \\
(\mathrm{mg} / \mathrm{mL})\end{array}$ \\
\hline \multirow{2}{*}{ A } & C. musae & $\mathrm{y}=2.3253 \mathrm{X}+5.7458$ & $0.9969^{* *}$ & 0.48 & 1.70 \\
\hline & F. semitectum & $y=1.801 x+6.0339$ & $0.9945^{* *}$ & 0.27 & 1.37 \\
\hline \multirow{2}{*}{ B } & C. musae & $y=2.0773 X+5.7290$ & $0.9966^{* *}$ & 0.45 & 1.85 \\
\hline & F. semitectum & $y=0.7945 x+5.7953$ & $0.9687 * *$ & 0.33 & 1.38 \\
\hline \multirow{2}{*}{$\mathrm{C}$} & C. musae & $y=3.1164 X+5.569$ & $0.9799^{* *}$ & 0.66 & 1.69 \\
\hline & F. semitectum & $y=1.6486 X+5.9269$ & $0.9976 * *$ & 0.27 & 1.64 \\
\hline
\end{tabular}

\subsection{Comparison of antibacterial effects of three component substances, carbendazim and prochloraz on two pathogenic bacteria}

From Figure 3 and Figure 4, the recommended 1mg / mL concentration of carbendazim and prochloraz have good bacteriostatic effects on the two pathogens, and the bacteriostatic rate against anthracnose pathogens is
$\mathrm{mL}$, respectively. It shows that the three components $\mathrm{A}$, $\mathrm{B}$ and $\mathrm{C}$ are more toxic to the pathogen of banana axis rot than the pathogen of anthracnose. From the EC90 value of the $\mathrm{A}, \mathrm{B}$ and $\mathrm{C}$ components to the two pathogens (both less than $2.0 \mathrm{mg} / \mathrm{mL}$ ), it can be seen that the three components have high virulence to the two pathogens and can be used as the two pathogens Good fungicide.

$79.45 \%$ (Figure 4A). The bacteriostatic rate against the pathogen of axis rot was $89.04 \%$ (Figure 4B). The $1 \mathrm{mg} /$ $\mathrm{mL}$ concentration of $\mathrm{A}, \mathrm{B}$, and $\mathrm{C}$ components is not as effective as carbendazim and prochloraz on bacteriostasis of two pathogens. The bacteriostasis rates of anthracnose pathogens are $71.92 \%, 71.91 \%$ and $69.75 \%$, the bacteriostatic effect of $\mathrm{A}$ and $\mathrm{B}$ components is better than $\mathrm{C}$ components. The bacteriostatic rates of the three component substances $\mathrm{A}, \mathrm{B}$ and $\mathrm{C}$ on the 
pathogen of axis rot were $72.1 \%, 70.54 \%$ and $72.74 \%$, respectively. There was no significant difference in the antibacterial effect between the three component substances. It can also be seen from Fig. 4 that the three component substances $\mathrm{A}, \mathrm{B}$, and $\mathrm{C}$ have a better bacteriostatic effect on the pathogens of shaft rot than the pathogens of anthracnose.
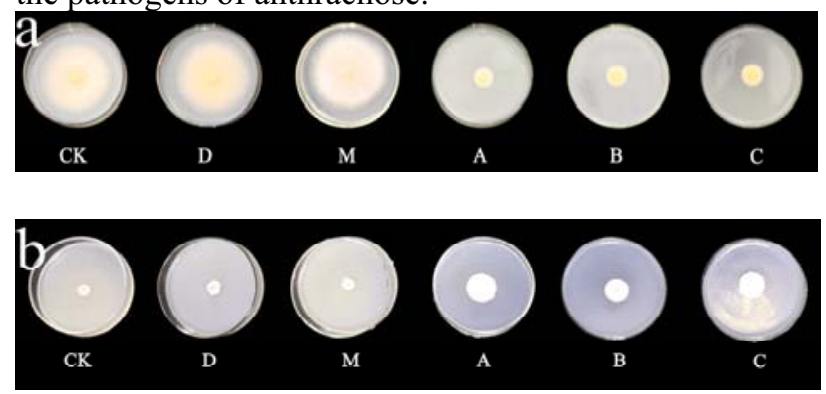

Fig.3 Bacteriostatic effects of three component substances, carbendazim, and prochloraz on banana anthracnose(a) and shaft rot(b) pathogens
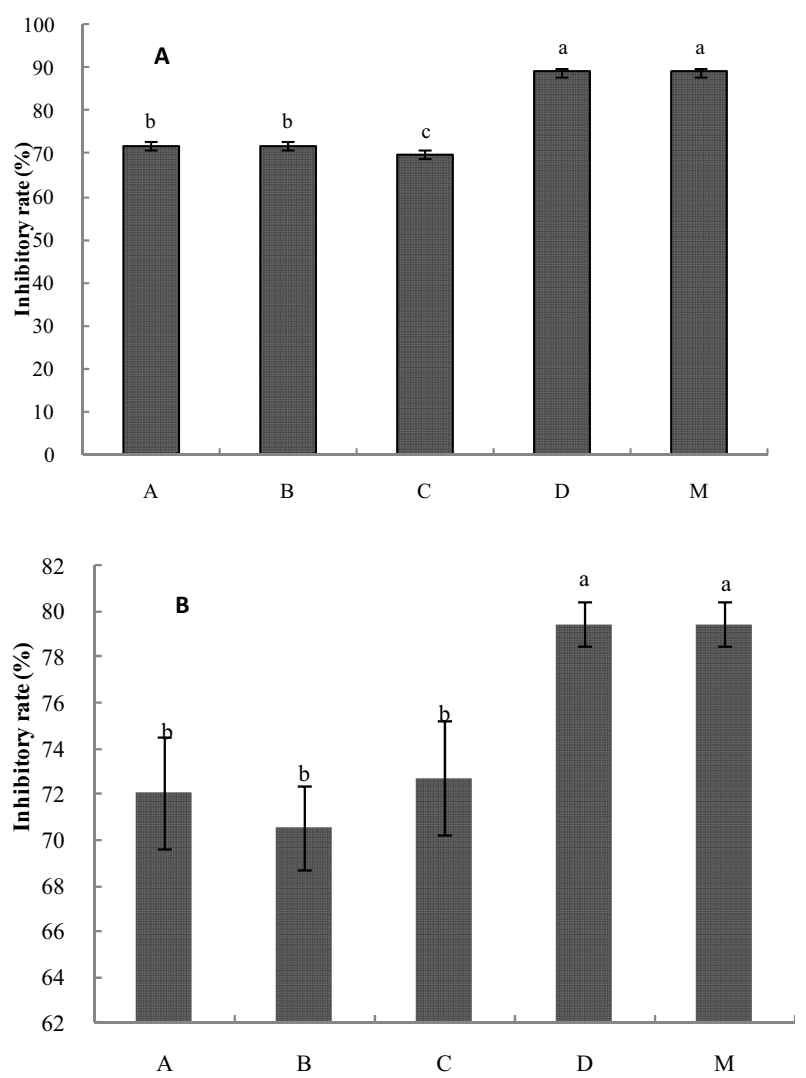

Fig.4 Bacteriostasis rates of three component substances, carbendazim, and prochloraz against banana anthracnose(A) and shaft $\operatorname{rot}(\mathrm{B})$ pathogens

\section{Discussion and conclusion}

According to reports, there are more than 6,300 higher plants with pest control in the world, including more than 2,000 sterilized plants. Our country is rich in natural resources and has very rich plant resources. At present, there are more than 1400 species of plants with fungicidal activity. Some medicinal plants have a good inhibitory effect on plant pathogens ${ }^{[12]}$. Hu et al. reported that acetone extracts such as cloves, cinnamon and fennel have a good inhibitory effect on postharvest pathogens of banana and mango fruit ${ }^{[5]}$. Studies by Yang et al. have found that Eupatorium adenophorum extract has significant inhibitory effects on banana anthracnose, anthracnose citrus, Phytophthora, Penicillium citrinum, etc. ${ }^{[13]}$. Ding et al. found that the petroleum ether extraction of the ethanol extract of Eupatorium adenophorum has a very strong bacteriostatic effect on Phytophthora infestans ${ }^{[14]}$. Studies by Li et al. had found that $70 \%$ ethanol extract of Eupatorium adenophorum has a significant inhibitory effect on Staphylococcus aureus, Bacillus subtilis, Bacillus thuringiensis, Escherichia coli, and Ralstonia solanacearum ${ }^{[15]}$. Zhao et al. reported that $100 \mathrm{mg} / \mathrm{mL}$ ethanol, acetone, and ether extracts have a good inhibitory effect on Fusarium graminearum and soybean anthracnose ${ }^{[9]}$. Studies by Ma et al. have shown that ethanol extracts and petroleum ether extracts of Eupatorium adenophorum can inhibit cucumis wilt, powdery mildew, tomato early blight, late blight, wheat powdery mildew, pear black spot disease and other pathogenic bacteria. The bacterial rate can reach more than $80 \%$, and the $\mathrm{EC}_{50}$ value of Eupatorium adenophorum extract and petroleum ether extract against pathogenic bacteria are both below $2 \mathrm{mg} / \mathrm{mL}$.

Utilizing the natural bactericidal active substance in Eupatorium adenophorum, it is developed into a plantderived fungicide for the green prevention and control of banana diseases and the preservation of fresh fruits after harvest. It has a broad market space. However, the chemical composition of Eupatorium adenophorum is complex, and the main reported ones are monoterpenes, sesquiterpenes, triterpenes, steroids, flavonoids, phenylpropanoids and related derivatives ${ }^{[16]}$. (Phenolic chemical composition in Eupatorium adenophorum) The antibacterial active substance may be a single component, or it may be a combination of several components. In this study, the leaves of Eupatorium adenophorum were crudely extracted with ethanol, and the crude extract was passed through The chromatographic column was initially separated to obtain three kinds of active substance components. The inhibitory effect of the three kinds of substance substances on two kinds of pathogenic bacteria was analyzed under in vitro conditions, and whether these active substance components are single substance components or are still mixtures The components, the antibacterial action mode and action mechanism of their active substances need further study.

According to the results of this experiment, although the three component substances at a concentration of 1 $\mathrm{mg} / \mathrm{mL}$ are not as effective as carbendazim and prochloraz for the two pathogens, the bacteriostatic rate for both pathogens is around $70 \%$ The $\mathrm{EC}_{90}$ value of the bacteriostatic effect of the two pathogens is less than $2 \mathrm{mg} / \mathrm{mL}$. Considering the environmental friendliness of plant-derived bactericidal active substances, the bactericidal effect on banana organisms needs to be further studied in order to eliminate the three component substances The development of plant-based fungicides to provide a theoretical basis for the green prevention and control of banana postharvest diseases. 
The components of the three Eupatorium adenophorum extracts tested all had good inhibitory effects on the banana anthracnose and axis rot pathogens tested. The $2 \mathrm{mg} / \mathrm{ml}$ concentration of the A, B and C components on the banana anthracnose and axis rot pathogens bacteriostatic rate reached $82.53 \%, 79.91 \%$, $78.30 \%$ and $82.2 \%, 78.69 \%, 81.17 \%$. The $\mathrm{EC}_{90}$ values of the components $\mathrm{A}, \mathrm{B}$ and $\mathrm{C}$ for banana anthracnose pathogens were $1.70,1.85$ and $1.69 \mathrm{mg} / \mathrm{ml}$, respectively, and the EC90 values for banana axis rot pathogens were $1.37,1.38$ and $1.64 \mathrm{mg} / \mathrm{mL}$, respectively. The inhibitory effect of the three components on the pathogen of banana axis rot is better than that of anthracnose. The three component substances have great potential for the prevention and treatment of banana postharvest anthracnose and shaft rot. It is worth further separation, purification and structural identification, and they are developed into plant-based fungicides for green prevention and control of banana postharvest diseases. Keep the fruit fresh.

\section{Recommended reason}

1. The work described has not been submitted elsewhere for publication, in whole or in part, and all the authors listed have approved the manuscript.

2. Banana anthracnose and shaft rot are main postharvest diseases. Crude extracts of Eupatorium adenophorum have great potential against two pathogenic bacteria of banana.

\section{Acknowledgements}

Financial support was by Shanxi Province Key R \& D Plan Project (201803D221011-5); Shanxi Agricultural University Science and Technology Innovation Fund Project (2017ZZ09); Fundamental Scientific Research Funds of Chinese Academy of Tropical Agricultural Sciences (No.1630062020030, No.1630062017017, No.1630062017025); Science Research Foundation of Yunnan Provincial Department of Education(2020J0250) and Special Research Project of College of Tropical Crop Science, Yunnan Agricultural University (2019RYZX001).

\section{References}

1. D.M. Zhou, Z.Y. Gao, M Li,H.Q. Yuan, X.P. Feng, M.J.Hu, Chinese Tropical Agriculture,03,3437(2018)

2. B.S.Wang, J.M.Liu, M.S.Cai, X.Chen, Guangdong Agricultural Sciences,06, 70-71(2004)

3. C.Z.Liu, B.S.Wang, P.K.Pei, J of Plant Pathology,03,21-25(1990)

4. X.H.Li,W.H.Feng,X.Yu,Y.Bi, J of Tropical and Subtropical Plants,01, 93-97(2009)

5. M.J.Hu,Z.Y.Gao,M.Li,F.Z.Yang,F.C.Zheng, J of Fruit Tree,03, 349-354(2007)
6. G.X.Wu,X.L.Yang,A.Y.Liu,W.X.Chen, J of Agricultural Engineering,07, 235-240(2007)

7. Y.B.He,R.L.Zan,Y.L.Zhao, Journal of Yunnan Agricultural U,06, 728-732(2006)

8. J.H.Ma, G.G.Xing, W.X.Yang, Acta Ecologica Sinica,32,50-56(2012)

9. C.F.Zhao,Y.Y.Wang,R.H.Liu,X.M.Xie,Hubei Agricultural Sci,06,1133-1135(2012)

10. Z.X.Huang, China Agricultural Press,56-59(1993)

11. F.Liu,R.L.Zan,J.G.Wei,J.M.Chang, J of Fruit Tree,29,428-433(2012)

12. Z.Yan,X.L.Mo,Y.S.Wang,Chinese J of Traditional Chinese Medicine,30,1714-1717(2005)

13. F.B.Yang,H.G.Zhou,Z.M.Xia,H.M.Ou,T.Y.He,W.X. Gu, Guangdong Agricultural Sci,38,83-84+97(2011)

14. J.H.Ding,Y.L.Yang,F.Y.Zhu,R.Z.Wang,L.T.Xiao, Journal of Hunan Agricultural U,06,751-753(2007)

15. L.P.Li,X.M.Xie,H.Y.Song,B.Q.Zhu, Biotechnology bulletin,07,146-152(2010)

16. M.Zhang,Z.Y.Zhou,H.Ren,J.W.Tan,F.H.Wan, J of Tropical and Subtropical Plants,01,63-68(2013) 